were willing to testify, for his evidence would be a confession against himself:" Griffin v. Brown, 2 Pick. (Mass.) 308. See, also, Vowles v. Young, 13 Ves. 144; Williams v. Johnson, 1 Str. 504, and Henman v. Dickinson, 5 Bing. 183, where, the suit being by indorsee against acceptor, and the defence fraudulent alteration by drawer after acceptance, the wife of the drawer was allowed to prove such alteration.

Stewart Repalje.

( $T o$ be continued.)

\title{
THE EFFECT OF A RECENT DECISION ON THE LAW OF MARINE INSURANCE. ${ }^{1}$
}

In The Phoenix Insurance Co. v. The Erie and Western Transportation Co., 117 U. S. 213, it was held (BrableY, J., dissenting,) that (1) a carrier can lawfully contract with the shipper by his bill of lading " in case of liability to have the full benefit of any insurance that may have been effected upon or on account of said goods." (2) The insurer paying the loss is deprived of the right to sue the carrier by whose negligence the cargo was lost.

The result in this case of the decision by a court of such importance as the Supreme Court of the United States on the right of a shipper to agree with his carrier to give the latter the benefit of the separate contract of the former with a third party (the insurer) would excite surprise if it was not also the conclusion of other respectable courts on the same subject.

It points out very clearly that a different train of thought is excited in the minds of underwriters and their adjusters from that of the judiciary by the presentation of the same facts; which is right and which is wrong is immaterial, for the law is on the side of the courts, even if the weight of reason is the other way. The minds of lawyers are submissive to authority and not critical. It will not, however, be thought captious to point out what other conclusions must follow from this ruling.

\footnotetext{
1 'This article was received too Iate to append it as a note to the cnse to which it relates, which is reported in the May number (ante, p. 330), and which will also appear in 117 U. S. Reports 213. The article contains the dissenting opinion of Mr. Justice Bis.dLEY, hitherto unpublished.
} 
While underwriters believed that they only agreed to indemnify those they agreed to insure and who paid the price for the risk assumed, the law is otherwise, in spite of the strong dissent of Mr. Justice BRADLEY, hereafter reported, and the insurers of shippers under these bills of lading, not only agree to indemnify their assured from loss, but also any carrier with whom the insured had no transactions, from the liability he may incur by negligently destroying the property intrusted to his care; so that a carrier who, in the course of his employment, destroys the cargo he became possessed of for the lawful purpose of carrying, becomes ipso facto by the terms of the modern bill of lading indemnified $a b$ initio for his future wrong, in the same manner, as the six carpenters who ientered lawfully on the premises of another on a breach of duty or behavior, became trespassers $a b$ initio.

Nor does the opinion of the dissenting judge stand alone. The claim of the carriers to be indemnified by insurers of the shippers from their relation to the cargo, has been presented before and has been denied by Chief Justice TIndal, in Yates v. Whyte, 4 Bing. N. C. 272 , who said it would be to hold that the wrongdoer should be permitted to take all the benefit of the policy without having paid the premium, and by Mr. Justice GRIER, in The Monticello, 17 How. 153, who pointed out with some warmth, when this proposition came before him, that the insurer was not a joint trespasser with the carrier, so that payment by one is a release of the other: (at p. 155.)

This view of the relation of the insurer to his insured has been obliterated by the decisions which culminated in the above decision at Washington.

\footnotetext{
It was probably in consequence of these and other decisions that the clause in question was inserted in the bill of lading of the large carrying companies, which have increased in length until they have become treatises on the law of carriage with many, if not most, of the decisions of the courts reversed by agreement of the parties. This remark will especially apply to through bills of lading, which, under their many exceptions of liability agreed upon, or rather insisted upon by the carrier, are substantially agreements to deliver the goods at destination, if it should happen that they arrive there in safetr. The carriers of a more humble class still con-" fine their exceptions of liability to that of fire, which is now excepted by law as to ship-owners, and the old-fashioned limitations of the act of God and public enemies. The clause now sustained will probably be universally adopted, and be met by an agreement of insurers to increase the premiums where the carrier's liability is limited, and to aroid the policy if the shipper destroys his insurer's right of reclamation against the carrier.
} 
A short sketch of these decisions may not be uninteresting, and will be of value to such lawyers as are interested in the very important and by no means artificial subject of the law of insurance.

In 1859 the Court of Appeals of New York, in MLercantile Ins. Co. v. Caleb, 20 N. Y. R. 173, suggested, although it did not so decide, that a carrier could obtain by agreement the benefit of his shipper's insurance without the consent of the insurer, although the courts of the same state had in effect decided the very reverse when they held that if the shipper surrendered to the carrier any right of reclamation, which his insurer paying the loss would become entitled to by subrogation, he pro tanto discharged the insurer whose rights were involved: Atlantic Ins. Co. v. Storrow, 5 Paige 285. Chief Justice GIBson decided similarly as to insurances by mortgagees, in Smith v. Columbia Ins. Co., 17 Penn. St. 253.

The same must be said of the English decision (Tate v. Hyslop, L. R., 15 Q. B. Div. 375,) in which BRETT, the Master of the Rolls, is in the Supreme Court decision correctly stated as saying in effect " the omission of the assured to disclose their agreement with the lighterman could only have affected the amount of salvage, which the underwriters might have had, and would have been immaterial to the risk, and consequently to the insurance;" but as he, as well as all the other judges who united in the opinion decided the reverse, viz., that where the insured failed to notify his insurer that he had relieved his carriers by contract, from full liability at law, he thereby failed to communicate a fact material to the risk, and the insurer was discharged. The two rates of premium adopted by the insurer showed that it was material to the risk.

This case, although cited as an authority in the decision of the Supreme Court, cannot be so considered; the sentence quoted is: the decision is otherwise.

The other decisions may be briefly summarized as follows :

In the case now under discussion, which was heard on appeal from the Circuit Court of Wisconsin (reported in Lawson on Carriers 382; also 10 Bissell 18-38), the carrier had inserted in his bill of lading the clause whose validity is now finally sustained. "The carrier so liable shall have the full benefit of any insurance that may have been effected upon or on account of said goods;" it was held by the District Court of Wisconsin and by the Cir- 
cuit Court on appeal, that as the carrier could insure his liability arising from the negligence of the servants, he could stipulate that his shipper should give him the benefit of his insurances, and thus destroy the right of the insurance company to sue for the loss sus. tained by the default of the carrier on payment to their insured.

The Circuit Court for the Southern District of New York, in Rintoul v. Railroad, 17 Fed. Rep. 903 (also 21 Blatch. 430, and 23 Am. Law Reg. (N. S.) 294), followed, for the same reasons.

This is certainly, however, not a self-evident proposition. Neither court adverted to the enormous difference which exists between the rights of a shipper who paid the premium and the carrier who did not. Nor did either court advert to the fact that it was a bargain in which the insurer, who is a surety only, had a right to be consulted. But they at once judicially transformed the right of subrogation by this one-sided contract, converting the subrogation of a surety for the injury done to his principal, into that of a trespasser against the surety of the party whom he had wronged by his neglect. - A strong sense of humor might have prevented these conclusions, which seem a paradox on the beneficent law of subrogation.

Judge WALLACE, in The Hadji, 22 Blatch. 235, decided that a stipulation "that no damage that can be insured will be paid for," was invalid, "because it would compel the owners of the goods to insure against the negligence of the carrier." Although this ruling is distinguished from the case of a claim to have the benefit of any insurances effected upon the goods, it is safe to say that in the case of ocean transportation, where all cargoes are insured, the two stipulations mean, and are in effect the same thing, as with the limited liability of owners and the excepted risks of the perils of the seas-prudence requires all cargoes to be insured. The amount of marine risks taken proves this. If marine insurance was an exceptional incident of ocean transportation, the distinction might be a substantial one, as it is it is only verbal. This is what the late Mr. Justice GRIER termed law for professors as distinguished from the law for business.

Next came Carstairs v. Insurance Co., 13 Fed. Rep. 823, followed in $18 \mathrm{Id}$. 473, in which the Circuit Court of Maryland, not feeling itself bound to disagree with the conclusions of the other Circuit Courts that a public carrier could exact such a stipulation from his employer, followed these decisions to the necessary conclusion, that the shipper by destroying his insurer's right of reclama- 
tion against those who injured the insured goods necessarily avoided the policy. Of the correctness of this conclusion there can be no fair doubt ; it is self-evident as soon as it is admitted, as was decided in Hall v. Railroad Co., 13 Wall. 367, that the contract of insurance was one of indemnity only.

This last case in the U. S. Circuit Court for Maryland attracted much attention; it was thought by some that this decision had put an end to the distressing questions which sprang up in the settlement. of carriers' losses. Large fires at railroad terminal shipping points, had given rise to lawsuits to adjust the losses between the two sets of insurers of the shipper and the railroad; for it might well be asked, how can the courts by any process of reasoning give the carriers the benefit of the insurances, which by the terms of their own bills of lading, they had made void and of no effect.

But the Supreme Court of Massachusetts relieved the courts of this difficulty, in Jackson v. Boylston Insurance Co., 139 Mass. 508 , by deciding that the rule in Carstairs v. Insurance Company, only applied where the insured agreed by the policy to give the insurer subrogation to his claim against the carrier, not adverting to the fact that the right was given by law the moment the insurance was made, and without such agreement being entered. (See all the cases from Mason v. Sainsbury, 3 Dougl. 61, decided in 1782 , to Mobile v. Jurey, in 111 U. S. 584, decided in 1884.) It can bardly be that such an agreement could have any greater effect than a notice to the assured of the rights of the insurer.

It is proper, however, to advert to one reason given by the $\mathrm{Su}$ preme Court of Massachusetts, which is more specious than real; that is, that the acceptance of a bill of lading with the usual exception of liability for loss by fire, would, if the rule in Carstairs v. Ins. Co. was insisted on, also vitiate the policy. This, however, is subject to the consideration, that the fire exception is universal in all bills of lading, is so well known, and for so long a time, that every insurer who takes a risk on goods in carriage, knows that the shipper has agreed to that exception in his contract of carriage; and therefore knows that he insures goods with this limitation of the carrier's liability. The insurers accept such risks with notice derived from the universal custom, and this is consistent with the view of the ISing's Bench Division in the case cited in the Supreme Court.

There are other decisions somerhat similar, but they need not be Voz. XXXIV. -47 
adverted to, one of which, in the Circuit Court of South Carolina (not reported), held that the shipper could not recover from a carrier unless he surrendered his policy, is notable.

All the courts seem to agree, that it was just and proper, that the carrier, the moment he became in default, and only then, should be indemnified by the insurer of the shipper, who had hitherto looked for reclamation, in the nature of salvage, from the party who injured the subject insured, and who by this bill of lading became insured, as respects the insurer.

The Supreme Court of Texas, in Insurance Co. v. Railroad, 63 Texas Rep. 471, carried the conclusion to its full and necessary.result, if the premises are granted, by holding that a carrier may bring a suit against the insurers of any. of their shippers, and recover the loss which the carrier had paid the shipper. As these views are sustained, and fully, by the Supreme Court of the United States, it is well to call attention to the vigorous dissent of Mr. Justice BradLEY, orally delivered, as follows :

"The law gives to the insurance company paying the insurance a right to be subrogated to the claim which the owner has against those who caused the injury which the insurer is called upon to repair. The thing insured, in this case, was cargo, for which the owner received a bill of lading: this bill contained an agreement between the owner of the cargo and the carrier, that the latter should have the benefit of any insurance effected on the cargo, by paying loss if liable. Now I say:

“1. This agreement in the bill of lading was res inter alios acta, as to the insurer, and he was not bound or affected by it. He had no notice of it. It was a fraud as against him. The owner of the cargo did not give up his right to sue the carrier and make him pay the loss. Had he done that, the subrogation of the insurer in the owner's place might be unavailing. The owner did not give up his own right to sue the carrier: he simply agreed with the latter, that the insurer should not have his legal right of subrogation, but should be answerable over to the carrier, if the latter paid the loss This conspiracy against the insured behind his back, should bo frowned upon by the law.

"2. The owner of the goods played a double part-he agreed with the insurer (i.e. the law implied an agreement), that the insurer, if he paid the loss, should be subrogated against the carrier, and he agreed with the carrier (privately), that if he paid the loss, he should be subrogated against the insurer. 
"Now by this double dealing of the owner, the two parties, insurer and carrier, were placed in this relation to each other, namely: one of them must lose something-who ought it to be? The inno. cent insurer, whose legal rights were well known to the carrier; or the carrier by whose fault the loss occurred, and whose claim as against the insurer arose by a secret stipulation with the owner of the goods not communicated to the insurer? Surely the latter should bear the loss."

It is proper, therefore, to consider what will be the effects on acjustments of marine losses, by this bill of lading, which is now very generally adopted, and we may fairly believe will become universal. The case as presented, sustains the decree of the court below in favor of the insurers for a sum adjusted in general average. The adjustment is not set ont, nor what was included in it. It is not adverted to in the decision, because, as the carrier did not appeal from the decree against him, it could not be reversed : (The Dove, $91 \mathrm{U}$. S. 381; The Stephen MIorgan, 94 Id. 549); and the opinion of the Supreme Court does not touch the question. If the insurers were liable for a partial loss, they were equally liable for a total loss, and there is no reason why they should recover for a partial loss occasioned by the fault of the carrier, if they were not entitled to recover for a total loss. The clause in bills of lading, which is a contract betreen the shipper and carrier, and to which the former's insurer is not a party, gives indemnity to the carrier only in case he is negligent or in default, so that in a case of fortuitous loss or inevitable accident, it is ineffective to create any right to the shipowner in the policy of insurance on cargo. It is only when he or his servants fail in duty to their employer, that the "shipowner becomes entitled to indemnity from an underwriter on cargo with whom he has no transaction; and the underwriters on the vessel, if they have undertaken to indemnify him from the consequences of his servant's neglect to other interests as well as his own (as in the case of insurances with the collision clause) become absolved, reversing the understood rules of adjustment of losses between two classes of insurers.

It was pointed out by the ablest of English judges (JESSEL, M. R., in L. R., 5 Ch. Div. 509), that in such adjustments one must treat the merchant and his insurers as one party, and the ship or warehouseman and his insurers as another party, and arljust the indemnity according as liability or otherwise is incurred by the insured bailee for the loss. Now this result seems necessarily to follow in the law of 
marine insurance. If any sacrifice of cargo or salvage expenses to cargo are incurred arising from negligent navigation, such sacrifice and expenses must, under the terms of this clause, be borne by the insurers of the cargo sacrificed, because, by the law merchant, all expenses incurred by the shipowner's fault, entail full liability on the shipowner, and are, therefore; excluded from general average; so that by virtue of this clause in the bill of lading, as soon as the liability of a shipowner for such default is established, it is to be borne by the insurers on cargo ; such expenses when excluded from general average, will be thrown on the insurers of the cargo and the insurers on hull escape all contribution for a loss which otherwise the law, for reasons of the highest policy, throws on the shipowner alone; while therefore a fortuitous accident gives rise to a general average contribution, negligent navigation throws the the whole loss on the insurers on cargo. Is not this a premium on negligence?

The result of this decision must give rise to difficulties in applying the law of damages arising from collision, which, in the case of cargoes, are generally insurance losses. Steamships also now generally carry policies with the collision clause indemnifying them from the consequences to their cargoes, and also to other vessels and their cargoes when the vessel is in fault.

The American rule differing from that of England, is that in collision the cargo does not share in the fault of the ship, so that although the ship may be condemned in half damages the cargo owner recovers in full the loss, being apportioned between the two ressels : The Milan, Lush. R. 398; The Alabama \& Gamecock, 92 U. S. 195. For this reason the cargo is called "innocent," as not sharing in the fault of its carrier vessel. The effect of this clause in the ship's bill of lading will give rise to curious results. In case the carrier ship is condemned in half damages it is adjudged to pay onehalf of the loss of its cargo in contribution with the other ship; now as its own liability to that extent is, by the terms of this bill of lading, indemnified out of the insurance on its cargo, the insurer on the hull of the vessel escapes the payment of that part of the loss he has agreed to pay. The insurers of the "innocent cargo" pay the whole loss, and the "guilty " vessel, as it is termed, and its insurer against collision escape. The same result also follows if the carrier vessel is wholly in fault. The terms "innocent " and "guilty" are singularly out of place in describing such subjects of insurance, 